\title{
Analysis of Broiler Chicken Demand Influencing Factors in Pematangsiantar City
}

\author{
R Hajiis, A H Daulay, E Mirwandhono, T H Wahyuni, Hamdan \\ Animal Production Program Study, Faculty of Agriculture, University of North \\ Sumatera, Medan 20155, Indonesia \\ E-mail: restuhajiis1@gmail.com
}

\begin{abstract}
Broiler chickens is a type of chicken that are able to grow and develop quickly. In addition, broiler chicken is one of favourite source of meat.

The purpose of this research was to determined the affecting factors of demand of the broiler chicken meat demand in the Pematangsiantar city. The study was conducted in AprilJune 2018 using primary data. The method used in accidental sampling is respondent interview with purposive technique that analyzed by Multiple Linear Regression using SPSS 22 application tool.

The results showed that broiler chicken demand in Pematangsiantar city was influenced simultaneously by broiler price, age, family member, family income, egg price, appetite level, and education level with $\mathrm{R}^{2}=0,51$. The price of broiler chicken meat, age and the number of family members had a significant effected on the $95 \%$ confidence level.
\end{abstract}

\section{Introduction}

In Indonesia, broiler chicken is one of livestock that very fast to grow. It only 4-6 weeks can be harvested with a body weight of $1.5-1.6 \mathrm{~kg} /$ head[1].

The consumption of broiler chicken increased because number of local chicken population is lower and difficult to obtain in the market, broiler chicken meat is cheaper and easily found in the market, and broiler meat texture is softer so it requires relatively fast time in processing[2].

The number of broiler chickens continues to increase. This also states that the demand for broiler chicken meat in North Sumatra has increased.Some cities in North Sumatra haven't a broiler population that areSibolga, Tanjungbalai and Pematangsiantar. Judging from the population of pematangsiantar city, it has the largest of population so that it is the author's aim to conduct research.The broiler chickens demand in the Pematagsiantar City is high enough in 2013-2017 that are $1,169,000,1,170,800,1,180,800,1,161,120$ and $1,132,420 \mathrm{~kg}$ although the population of broiler livestock in the Pematangsiantar City is nothing. So that the consumption needs of broiler chickens are filled from outside the PematangsiantarCity[3]. The demandof broiler chicken in Medan are influenced by the level of income, education and the number of family [4]. The broiler chicken prices, price of eggs, income,number of family members, age, taste dummy, and dummy of education significantly influence the demand of broiler chicken in citeureup market of bogor subdistrict[5].

The purpose of this research was to determined the affecting factors of demand of the broiler chicken meat demand in the Pematangsiantar city.

\section{Method of Research}

2.1.Time and place of research

This research was conducted from May to June 2018 at the Traditional Markets of Pematangsiantar City for two month. The location of this study was determined purposively with the consideration that this location has not broiler population but there is a demand for broiler chiken. 


\subsection{Sample Determination Method}

The method of determining consumer samples is done by purposive method (intentional), namely taking respondents who are consumers who happen to shop broiler chicken meat in the traditional DwikoraParluasan and Horas market. With the following conditions: the sample is a consumer who is shopping for broiler chicken meat to be consumed instead and not resale The sample taken in this study is 30 samples for each market.

\subsection{Method of collecting data}

The data used in this study are primary data and secondary data. Primary data obtained from interviews with consumers of broiler chicken meat using a list of questions / questionnaires that have been made previously. Secondary data was obtained from relevant agencies and agencies such as the North Sumatra Security Food and Livestock Office, The Central Statistics Agency (BPS) and other relevant agencies as well as other literature such as journals and the results of previous studies that supported this research.

\subsection{Analysis method}

The analytical method used in this study is descriptive and inductive analysis. Descriptive analysis method aims to determine the characteristics of broiler chicken meat consumers. Inductive analysis is analyzing the factors that influence the demand of broilers chicken meat, namely the price of broiler chicken meat, family income, sum of families member, level of education, age, price of broiler eggs and taste level calculated by estimating multiple linear regression with SPSS 22 .

2.4.1 Multiple Linear Regression Analysis

Multiple linear analysis estimation model as follows:

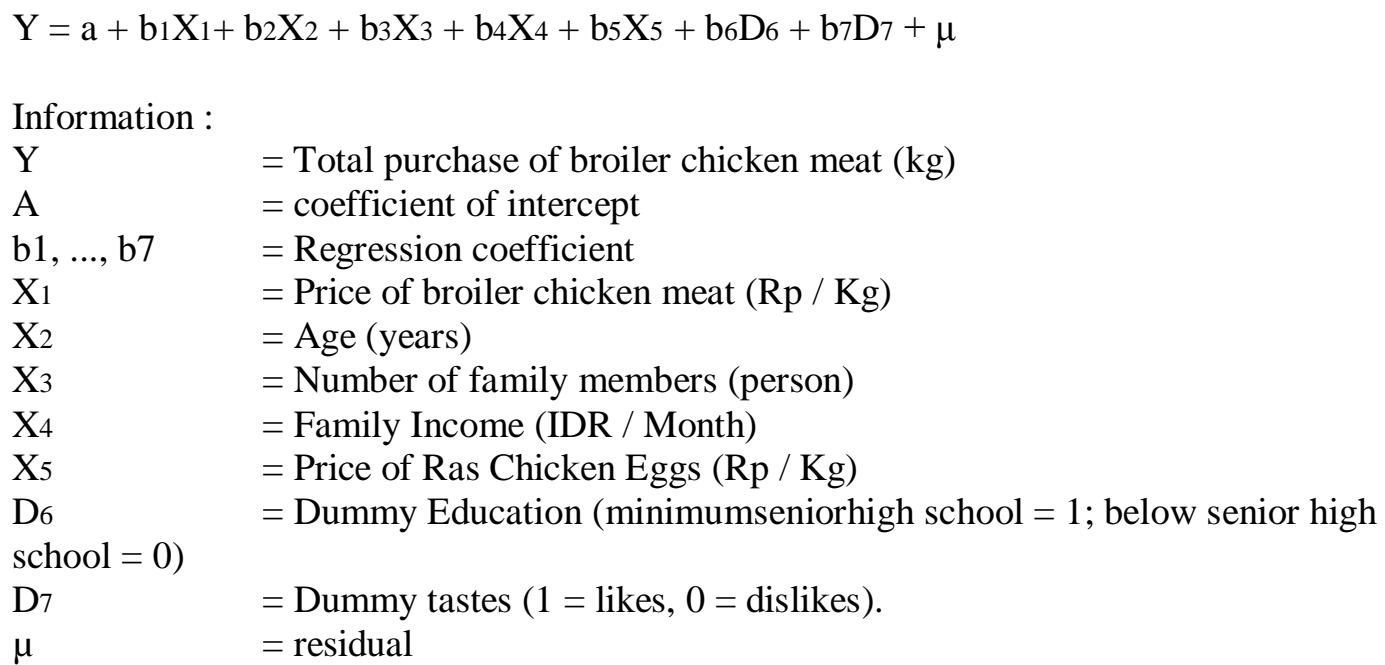

\subsubsection{Test Of Goodness Of Fit}

a. Determination Coefficient $\left(\mathrm{R}^{2}\right)$

This coefficient is a measure of the extent to which independent variables can change the dependent variable in a relationship. This coefficient shows the percentage of free variation[4].

The coefficient of determination $\left(\mathrm{R}^{2}\right)$ ranging from $0<\mathrm{R}^{2}<1$ to the test criteria is that $\mathrm{R}^{2}$ which is closer to 1 indicates that the model formed is able to explain the diversity of the dependent variable. The higher the $\mathrm{R}^{2}$ value, the better.

\section{b. Simultaneous Test (F-Statistic Test)}

$\mathrm{F}$ test is a simultaneous test of the effect of independent variables on fixed variables. The $\mathrm{F}$ statistic test shows whether all the independent variables included in the model have a joint influence on the dependent variable.

Testing criteria 
1. If sig. $\mathrm{F} \leq 0.05$ then $\mathrm{H} 0$ is rejected and $\mathrm{H} 1$ is accepted

2. If sig. $\mathrm{F}>0.05$ then $\mathrm{H} 0$ is accepted and $\mathrm{H} 1$ is rejected

\section{c. Partial Test (Statistic Test)}

The $t$ test is a test of the effect of independent variables one by one affecting the dependent variables. The significance level $(\alpha)$ used is $5 \%$. The $t$ test to be carried out is:

1. The influence of the price of broiler chicken meat on the amount of broiler chicken meat demand.

2. The influence of family income on the amount of demand for broiler chicken meat.

3. The influence of the number of family dependents on the amount of broiler chicken meat demand.

4. The influence of age on the amount of broiler chicken meat demand.

5. The influence t of egg prices on the amount of broiler chicken meat demand.

6. The influence of education on the amount of demand for broiler chicken meat.

7. The influence of appetite level on broiler chicken meat demand

Testing criteria:

1. If sig. $\mathrm{t} \leq 0.05$ then $\mathrm{H} 0$ is rejected and $\mathrm{H} 1$ is accepted

2. If sig. $\mathrm{t}>0.05$ then $\mathrm{H} 0$ is accepted and $\mathrm{H} 1$ is rejected

\section{Results and Discussion}

\subsection{Regression Equations}

Regression estimation equation is a systematic formula that shows the relationship between one variable or several independent variables on the dependent variable. Based on analysis of research data result, the regression equation of the factors that influence the demand of broiler chicken meat in Pematangsiantar city is as follows:

$\mathrm{Y}=0.665-0.00004158 \mathrm{X}_{1}+0.008 \mathrm{X}_{2}+0.129 \mathrm{X}_{3}-0.00000001142 \mathrm{X}_{4}+0,000454 \mathrm{X}_{5}+0,098 \mathrm{D} 6$ $+0,021 \mathrm{D} 7$

Information:

$\mathrm{Y}=$ Total purchase of broiler chicken meat $(\mathrm{Kg})$

$\mathrm{X}_{1} \quad=$ Price of broiler chicken $(\mathrm{Rp} / \mathrm{Kg})$

$\mathrm{X}_{2} \quad=$ Age $($ Year $)$

$\mathrm{X}_{3}=$ Sum of family members (person)

$\mathrm{X}_{4} \quad=$ Family income $(\mathrm{Rp} / \mathrm{month})$

$\mathrm{X}_{5} \quad=$ Price of eggs $(\mathrm{Rp} /$ item $)$

D6 $\quad=$ Dummy Level of taste (likes $=1$; dislike $=0)$

D7 $\quad=$ Dummy Education (minimum senior high school $=1$; below senior high school $=0$ )

\subsection{Determination Coefficient Test $\left(\mathrm{R}^{2}\right)$}

Test the coefficient of determination is to find out how far the independent variables affect the dependent variable. Based on data analysis, a determination coefficient 0.51 it is means the independent variables that have been used can influence the dependent variable by $51 \%$ while $49 \%$ is influenced by other factors not included in the demand function (Y).

Table. 1 Determination Coefficient Test $\left(\mathrm{R}^{2}\right)$

\begin{tabular}{cccc}
\hline $\mathrm{R}$ & $\mathrm{R}$ Square & Adjusted R Square & Std. Error of the Estimate \\
\hline $0,714^{\mathrm{a}}$ & 0,51 & 0,444 & 0,24093 \\
\hline
\end{tabular}

\subsection{Simultaneous Test (F Statistics)}

Statistical $\mathrm{F}$ test is a test to see the effect of independent variables simultaneously affecting the fixed variable. The entire independent variable is said to affect the dependent variable if the probability value is smaller than 0.05 . From the results of the analysis the probability is smaller than 0.05 , which means that the price of broiler chicken meat, age, sum of family members, family income, egg prices, food, taste, and education spending simultaneously affect the demand of broiler chicken meat. Therefore, the next test is the statistical $t$ test to see the variables that affect the demand of broiler chicken meat. 
Table. 2 Result of F statsitik test

\begin{tabular}{|c|c|c|c|c|c|}
\hline Model & $\begin{array}{l}\text { Sum of } \\
\text { Squares }\end{array}$ & df & $\begin{array}{l}\text { Mean } \\
\text { Square }\end{array}$ & $\mathrm{F}$ & Probability \\
\hline Regression & 3,136 & 7 & 0,448 & 7,718 & $0,000^{b}$ \\
\hline Dacidunl & 3010 & 52 & ก ח58 & & \\
\hline \multicolumn{6}{|c|}{ Table. 3 Result T statistik test } \\
\hline $\begin{array}{r}\text { Model } \\
\end{array}$ & & $\mathrm{t}$-value & \multicolumn{3}{|c|}{ P-value } \\
\hline (Constant) & & 1,128 & \multicolumn{3}{|c|}{0,264} \\
\hline Broiler chiken price & & $-2,397$ & \multicolumn{3}{|c|}{0,020} \\
\hline Age & & 2,284 & \multicolumn{3}{|c|}{0,027} \\
\hline Sum of family member & & 5,756 & \multicolumn{3}{|c|}{0,000} \\
\hline Family income & & $-1,179$ & \multicolumn{3}{|c|}{0,244} \\
\hline Egg price & & 1,972 & \multicolumn{3}{|c|}{0,054} \\
\hline Taste level & & 1,331 & \multicolumn{3}{|c|}{0,189} \\
\hline Education level & & 0,324 & \multicolumn{3}{|c|}{0,747} \\
\hline
\end{tabular}

\subsection{Partial Test (Statistical T Test)}

This partial test aims to determine what factors are among the independent variables that affect the demand for broiler chicken meat in the Pematangsiantar City. If the independent variable has a probability smaller than 0.05 , this variable significantly affects the demand for broiler chicken meat that are broiler chiken price, sum of families member, and age.

\subsection{The Factors Influence Broiler Chicken Meat Demand}

Based on the results of calculations on the partial regression coefficient test or $\mathrm{T}$ test obtained the following results:

1. Price of broiler chicken meat (X1)

Based on the results of the $t$ test analysis showed that the variable price of broiler chicken meat has a probability value of 0.020 smaller than 0.05 , which means that the price of broiler meat significantly affects the demand for broiler chicken meat in the city of Pematangsiantar. It is in line with a research conducted which states the demand for broiler chicken meat in the traditional market in the citeureup sub-district of Bogor district is significantly affected by the increase in the price of broiler chickens [6]. This proves that the community is also sensitive to the increase in the price of goods on the market. Based on the regression analysis that the coefficient value of the price of broiler chicken meat is 0.000004158 and has a negative sign which means that every increase of Rp 1 will reduce the demand for broiler chicken meat amounting to $0.00004158 \mathrm{~kg}$.

2. Age (X2)

Based on the analysis of the $t$ test that obtained the probability value of age is 0.027 smaller than 0.05 so that the age significantly affects the demand for broiler chicken meat. It is not in line with a research which states that the demand for broiler eggs in the city of Pematangsiantar is not significantly affected by age [7]. Regression analysis that the coefficient value of Age is 0.008 which means that if the age increases by 1 year then the number of requests will increase amounting to 0.008 $\mathrm{kg}$. Based on primary data, the highest age is at the age of $15-49$ years, which is $73 \%$, this proves that the most buyers of broiler chicken meat come from productive age groups.

3. Family Members (X3)

Based on the $t$ test analysis, the probability value 0,000 is greater than 0.05 , which means that the number of family members significantly affects the amount of broiler chicken meat purchases. This is in line with a research which states that the demand for chicken meat in Medan is significantly affected by the number of family members [4]. The sum of family members increase will increase the amount of demand for broiler chicken meat.Regression analysis that the coefficient value of family members is 0.129 , which means that every increase in the number of family members is 1 person, then the demand will increase amout $0.129 \mathrm{~kg}$. 


\section{Family Income (X4)}

Based on the $t$ test analysis that the value of the probability of family income is 0.159 greater than 0.05 , which means that family income does not significantly affect the amount of demand for broiler chicken meat. This is in line with a research which states that the level of income does not significantly affect the demand for broiler eggs in the city of Medan [8]. This is because the variable number of family members affects the demand for broiler chickens so that if the income increases but the number of family members remains the demand will not increase because it only buys for family enough. Regression analysis that the coefficient value of family income is 0.00000001142 and is negative, which means that every increase of $\mathrm{Rp} 1$ family income will reduce the demand for chicken meat amount 0.00000001142 . The higher the income, the community will choose foods that are considered more healthy such as organic food. According to some respondents, local chicken is healthier than broiler chicken meat because the cultivation process is more natural and does not contain inorganic ingredients and other synthetic chemicals.

\section{Egg prices (X5)}

Based on the analysis of the $t$ test that the probability value of the egg price is 0.054 greater than 0.05 , which means that the price of eggs does not significantly affect the demand for broiler chicken meat. It is in accordance with astatement which states that the price of eggs does not significantly affect the demand for broiler chicken meat in the Cietereupsubdistrict of Bogor district [6]. This is because chicken eggs have become food that must be available at all times, chicken eggs will still be available, both when there is or does not demand broiler chicken meat. This also proves that the substitute (broiler) meat items for the people of Pematangsiantar city are not eggs but other types of goods. Based on the regression analysis that the coefficient value of the egg price is 0.00507 , which means that every increase in the egg price of Rp 1 will increase the demand for broiler chicken meat amout to $0.00507 \mathrm{~kg}$.

\section{Taste level (D6)}

Based on the analysis of the $t$ test that the probability value of the level of taste is 0.747 greater than 0.05 , which means the level of taste does not affect the demand for broiler chicken meat. This is not in line with a research which states that the level of taste in broiler chicken meat significantly affects the demand for broiler chicken meat [6]. Based on the field this is due to the purchase of broiler chicken meat by consumers is determined not only from the consumers themselves but the wishes of the family such as husbands, children, other family members and as a variety of food. Based on the regression analysis that the value of the coefficient of the taste level is 0.21 , which means that every increase in taste will increase the number of requests amout to $0.21 \mathrm{~kg}$.

\section{Education Level (D7)}

Based on the analysis of $t$ test the probability value of the education level is 0.161 greater than 0.05 , which means that the level of education does not significantly affect the demand for broiler chicken meat. This is in line with a research which states that the demand for broiler chicken meat in the city of Medan is not significantly influenced by the level of education [7]. This is because broiler chicken meat is a type of food that is classified as common in the urban community of pematangsiantar so that every community is used to consuming it. Regression analysis that the value of the coefficient of education level is 0.105 , which means that every higher level of education will increase $0.105 \mathrm{~kg}$ of demand for broiler chicken meat.

\section{Conclusion}

The factors that influence simultaneously on the demand of broiler chicken meat in the city of Pematangsiantar are the price of broiler chicken meat, age, sum of family members, family income, eggs price, taste level and education level but the influence partially on the demand of broiler chiken meat in the City of Pematangsiantar are the price of broiler chicken meat, age, and sum of family members with coefficient determination $\left(\mathrm{R}^{2}\right)$ is $51 \%$. 
References:

[1] Yemima. 2014. Analisis Usaha PeternakanAyam Broiler padaPeternakan Rakyat di DesaKaryaBakti, KecamatanRungan, KabupatenGunung Mas, Provinsi Kalimantan Tengah.JurnalIlmuHewaniTropika Vol.3.No.1.Juni 2014 ISSN: 2301-7783.

[2] Murtidjo B. A. 2007. Pemotongan, Penanganan, danPengolahanDagingAyam. Yogyakarta: Kanisius.

[3] Dinas Ketahanan Pangan dan Pertanian Kota Pematangsiantar. 2018. Pematangsiantar.

[4] PranataEko. 2013. AnalisisPermintaandagingayam broiler/pedaging di kotamedan. (skripsi).Medan : FP USU.

[5] Supriana T. 2013. Pengantarekonometrika. USU PRESS: Medan

[6] Rohim Ashari.2017. AnalisaFaktor Yang MempengaruhiPermintaanDagingAyam Broiler Di PasarTradisionalKecamatanCiteureupKabupaten Bogor.(Skripsi).Bogor: FakultasEkonomi Dan Manajemen IPB.

[7] TampubolonBitaSerefina. 2016. "AnalisisFaktor-Faktor Yang Mempengaruhi Permintaan Dan PenawaranTelurAyamRas Di Kota Pematangsiantar". Skripsi. Program StudiPeternakanFakultasPertanianUniversitas Sumatera Utara. Medan.

[8] Sitorus S.A., 2015. AnalisisFaktor-faktor yang MempengaruhiPermintaandan PenawaranTelurAyamRas di Kota Medan (StudiKasus: PasarPetisah, medan). Universitas Sumatera Utara. Medan. 